\title{
Editorial
}

\section{Aspectos psicossociais na saúde: importância da prática interdisciplinar}

Os profissionais da saúde, especialmente na área de saúde pública, têm sido solicitados a tratar cada vez mais freqüentemente de demandas que escapam à mera oposição saúde-doença. Contrastando com a hegemonia do modelo biomédico, as dimensões psicossociais e políticas das práticas destes profissionais ampliam sua presença e questionam aquele modelo. O olhar ampliado sobre a saúde desafia a hegemonia que define as dimensões psicossociais como acessórias, com o caráter cultural e relacional da saúde tendenciosamente colocado de lado.

Este movimento, no entanto, não tem sido suficiente para superar as resistências quanto a considerar a complexidade das representações de saúde, doença, cura e tratamento. Nem tem sensibilizado suficientemente os profissionais sobre as relações entre saúde e o sofrimento social que assola populações socialmente excluídas, com importantes conseqüências para a definição de práticas de prevenção e cuidado. A reversão deste quadro nas ações contemporâneas em saúde requer que se coloque em destaque suas dimensões humana e social, implicando um manejo diferente do conhecimento que suporta estas ações.

Sob uma perspectiva interdisciplinar, práticas clínicas e pesquisas sobre diferentes dimensões da saúde e suas conseqüências vêm sendo conduzidas com pacientes atendidos no Ambulatório de Neuro-Sono das Disciplinas de Neurologia e Medicina de Urgência da UNIFESP. Neste serviço, médicos de diferentes especialidades, dentistas, fisioterapeutas, fonoaudiólogos, terapeutas ocupacionais, nutricionistas, educadores físicos e psicólogos, entre outros, interagem no cuidado de um objeto que não pode ser definido meramente como um corpo ou como uma doença. O desafio deste trabalho, que coloca saberes aparentemente tão distintos em jogo, está na construção de uma linguagem comum que não é feita apenas de palavras, mas de relações que suportem a diferença, o desejo de conhecimento e o compromisso com uma prática de saúde que respeita a complexidade psicossocial do seres humanos.

Os resultados que vem sendo conseguidos pelo Ambulatório, tanto no tratamento da clientela do serviço quanto na formação de profissionais, reforçam a importância de uma abordagem interdisciplinar para a compreensão dos aspectos psicossociais nas ações de saúde e que solicitam uma prática profissional que ultrapasse o espaço restrito da clínica, exigindo, além de capacitação técnica, um compromisso ético e político por parte dos profissionais de saúde.

Dr. João Eduardo Coin de Carvalho Psicólogo, Pesquisador do Ambulatório Neuro-Sono da UNIFESP e Professor do Curso de Psicologia da UNIP 